\title{
Racing car brings tear drops in the moose
}

\author{
Elizabeth Varkey Cherian, ${ }^{1} \mathrm{~K}$ Varadaraj Shenoy, ${ }^{1}$ Mario Joseph Bukelo, ${ }^{1}$ \\ Deepu Alex Thomas ${ }^{2}$
}

'Department of Pediatrics, Father Muller Medical College, Mangalore, Karnataka, India ${ }^{2}$ Department of Radiology, Father Muller Medical College, Mangalore, Karnataka, India

\section{Correspondence to} Dr Elizabeth Varkey Cherian, elizabeth.v.cherian@gmail.com
To cite: Cherian $\mathrm{EV}$ Shenoy KV, Bukelo MJ, et al. BMJ Case Rep Published online: [please include Day Month Year] doi:10.1136/ bcr-2012-008165

\section{DESCRIPTION}

The corpus callosum is a band of white matter connecting two cerebral hemispheres of the brain and responsible for the integration of motor, sensory and cognitive information. Its development starts in the first trimester of pregnancy, while maturation continues to childhood and adolescence. The true incidence and the precise aetiology of the anomalous development of corpus callosum are impossible to determine clinically without brain imaging.

Anomalies in the development of corpus callosum vary from partial, complete or atypical agenesis. They occur in isolation or in association with neuronal migration disorders, aneuploidy (trisomies 18 and 13), central nervous system (CNS) syndromes (Aicardi and Aperts syndrome), CNS associations (Arnold-Chiari and Dandy-Walker malformations) and certain inborn errors of metabolism of lactate and pyruvate.

The clinical spectrum of agenesis of corpus callosum varies from early mortality, seizures, poor developmental outcome, hypertelorism to mild learning disability ${ }^{12}$

Diagnosis can be made from antenatal ultrasound scans from the 20th week of gestation but multiplanar MRI, is the modality of choice, as it has better sensitivity to depict the associated anomalies, with its high soft tissue contrast (figure 1).

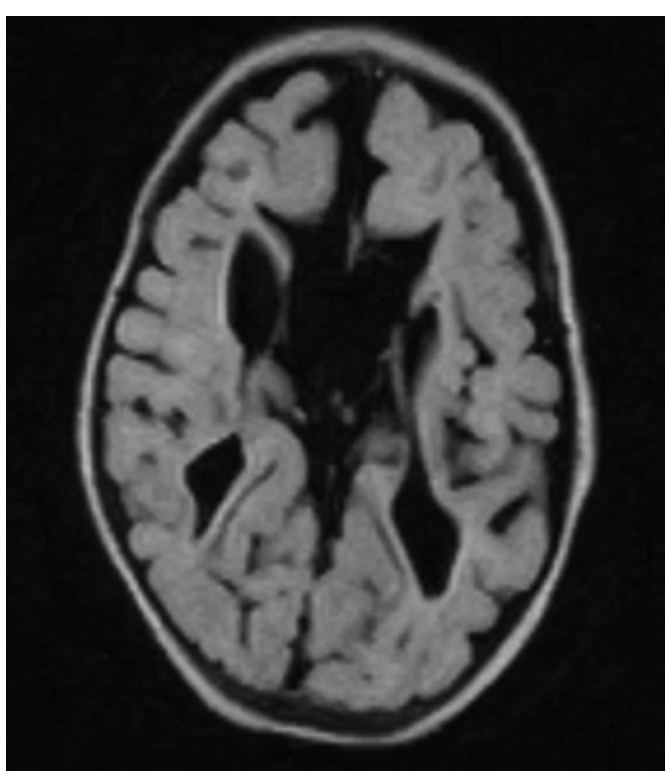

Figure $1 \mathrm{MRI}$ in agenesis of corpus callosum.

The MRI of brain with agenesis of corpus callosum show (figure 2)

1. The racing car sign: the two lateral ventricles of the brain are seen as parallel bodies from the midline. This resembles a formula one car

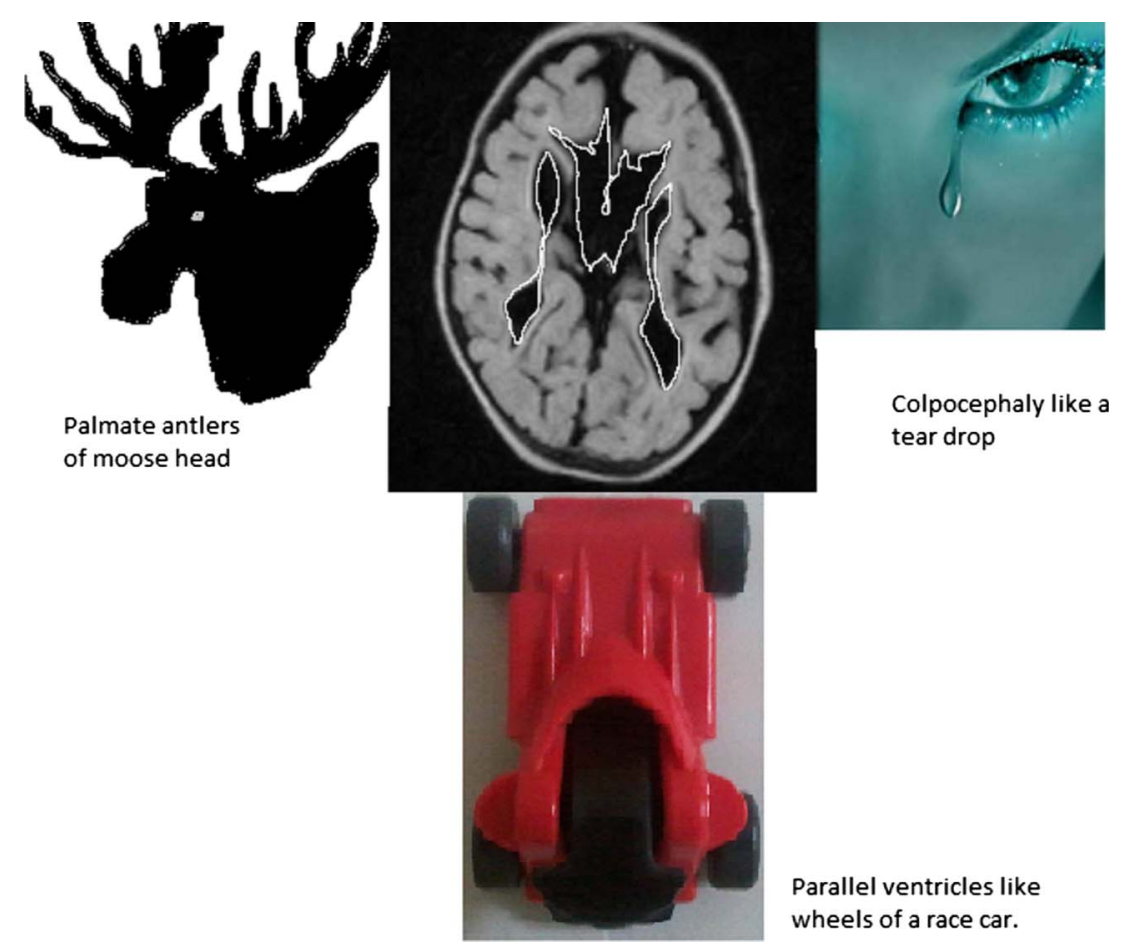

Figure 2 Cartoon image depicting the resemblance to a racing car, tear drop and moose head. 
seen from above, with tyres represented by the widely spaced frontal horns.

2. Tear drop sign-colpocephaly: the enlarged atria and dilated occipital horn of the lateral ventricles give a tear drop appearance.

3. Moose head sign: in the coronal section the interhemispheric fissure is in continuity with a dilated and dorsally elevated third ventricle. The lateral ventricles are indented medially by the Probst bundles while the frontal horns are sharply angulated and so resemble the palmate antlers of a moose.
Contributors EVC was responsible for patient care and manuscript draft. SKV is Head of Unit, consultant responsible for patient care. BMJ is a post graduate in pediatrics, involved in patient care. TDA is staff radiologist.

Competing interests None.

Patient consent Obtained.

Provenance and peer review Not commissioned; externally peer reviewed.

\section{REFERENCES}

1 Aicardi J. Aicardi syndrome. Brain Dev 2005;27:164-71.

2 Lau YC, Hinkley LB, Bukshpun $P$, et al. Autism traits in individuals with agenesis of the corpus callosum. J Autism Dev Disord 2012; Oct 5. doi:10.1007/s10803-0121653-2

\section{Learning points}

Spot diagnosis on MRI with the aid of mnemonic.

- Structural defect identification, for early diagnosis and to predict outcome.

Copyright 2013 BMJ Publishing Group. All rights reserved. For permission to reuse any of this content visit http://group.bmj.com/group/rights-licensing/permissions.

BMJ Case Report Fellows may re-use this article for personal use and teaching without any further permission.

Become a Fellow of BMJ Case Reports today and you can:

- Submit as many cases as you like

- Enjoy fast sympathetic peer review and rapid publication of accepted articles

- Access all the published articles

- Re-use any of the published material for personal use and teaching without further permission

For information on Institutional Fellowships contact consortiasales@bmjgroup.com

Visit casereports.bmj.com for more articles like this and to become a Fellow 